\title{
Empirical Analysis of Financial and Non-Financial Risks of the Commercial Bank
}

\author{
Asie Tsintsadze ${ }^{1}$, Vladimer Glonti ${ }^{2}$, Lela Oniani $^{3}$ and Tamar Ghoghoberidze ${ }^{4}$
}

\begin{abstract}
Background: Activities of commercial banks are connected with numerous risks, the source of which is the internal and external processes of the bank. Objectives: Risk management science has been studying the origins of the risks, determining their impact quality and avoiding expected loss models from the 1950s. Method/Approach: Credit risk regressive analysis is based on the selection of effective factors, determination of their influence and prediction of future according to the correlation coefficient. Results/Findings: In the article, it is discussed the regressive analysis of operational risk. Conclusion: The effect of credit and operational risks on the financial results of the Bank is based on the results obtained and recommendations have been developed to increase risk management efficiency.
\end{abstract}

Keywords: credit risk, operational risk, regressive analysis, risk management, forecasting.

\section{Introduction}

The international rules and mechanisms of banking regulation are concentrated on the reduction of credit risk quality; however, to protect them from it is still a problem. The reason for this is the diversity of factors related to credit operation, some of which have not yet been studied. Management of the Bank's assets and liabilities, Liquidity and ensure solvency feel of the impact of many risks. In such conditions, it is difficult to achieve the optimum ratio between "risk-income».

According to risk principals, the higher is the risk, the higher is the probability of profit. This principle is much easier to implement in another type of enterprise. The Bank is an organization that operates under double pressure. In particular, its activities are due to the economic agents operating in the economy, the companies operating internationally, the stock exchanges, decisions made by participants of the currency markets. Their financial outcomes constitute the basis for the Bank's activities, which is generated in profit. Banking Risk Regulation Mechanisms are built on the Bank's capital requirements. I.e. risk management is not so much directed towards revealing the expected risks but also to eliminate the consequences of the risks. Principle -"high riskhigh income" is attractive, but it is opposed to the principle -"Do not risk more than you have to." Modern risk management cannot regulate all risk. As studies show, commercial banks prefer financial risk analysis; they consider them to be "their own risks". At the same time, non-financial risks remain beyond attention, whose impact on financial risks

${ }^{1}$ Professor, Batumi Shota Rustaveli State University.

${ }^{2}$ Professor, Batumi Shota Rustaveli State University.

${ }^{3}$ Associate Professor, Batumi Shota Rustaveli State University.

${ }^{4}$ Doctorate, Batumi Shota Rustaveli State University. 
is very large. Types of non-financial risks, the factors of their origin and methodology of detection are not well studied.

After the 2008 banking crisis, risk management has faced the following tasks: To identify all the risks, with minimal impact on which the results were obtained. This task was caused because of Banking Supervision Regulatory Authorities have been recognized that risks that were not related to banking capital remained outside management. He was called "blind" risks and was given the category of non-financial risks. Various authors give us a different list of non-financial risks. Non-financial risks are a risk of behaviour, the risk of reputation, the risk of incompatibility.

The legal risk is the non-financial risk that affects not just at the profit of the bank, but also the reputation of the organization and the human capital. (Lopatnikov, 15, p.126) In order to accomplish the set objective, risk management must first identify all the risks that have occurred in retrospect, eliminating the risk of which the factor is no longer possible to add to the predictable risks in the perspective. The risks must be sorted according to non-financial and financial risks eliminate duplication. After that, it must be determined the quality of new risk and the quality of old risks must be corrected. Based on the received data Risk Management can build a more integrated, reliable methodology for risk management.

Increasing the quality of financial risks in recent years has increased the role of risk management and has provoked the tightening of regulatory mechanisms. However, non-financial risks are not still studied fully. Besides the fact that non-financial risks have a negative impact on the banking business, and an unfavourable conclusion is made about the expenses connected to the regulation of the risks. Risk culture is one of the conditions for reducing non-financial risks. It implies the establishment of the behaviour of the personnel and employees of all the Bank's staff and the risks to the organization, which will be directed towards achieving the goal. The professionalism of the staff is a main determining factor of behaviour risk, which is one of the criteria for getting a job, but its "indifference" is a threat to the risk of non-financial risk. The Bank's specialist is in contact with people, and his psychological aspect is more visible here, and regardless of strict control of behaviour rules, the appearing of risk has a high probability. Psychologists Krasnenkova N. E. And Yarushkin N.N. in the work "The formation of mechanism of social-psychological competence and psychological patterns of a bank employee" note that to increase confidence towards employing, it is necessary as to test professional skills, as permanently raise professionally important psychological knowledge, skills, habits, which determines the socio-psychological competence and provide a successful Professional activities. We agree with the authors about psychological control and development of the bank worker, but for the sake of perfection we suggest that the psychological aspect is hardly regulated and the final result is difficult to obtain (ie the person's conversion). The problems that exist in life infects to the psychological state of the person, and we believe that in the non-financial risk management methodology the Bank's internal social responsibility principles should be considered. As a result, the double effect is achieved: a professional staff will be maintained and reduced the expected losses from non-financial risks.

In world practice, most of the commercial banks' profit comes from credit operations. The bank, as an intermediary organization, may face a dual risk situation 
between the lender and the borrower. In the case, it can be the withdrawal of cash resources from the deposit before the deadline because of the financial problems of the lender, and secondly, the non-payment of the credit funds due to the bankruptcy of the borrower. Credit risk management requires constant control of the credit portfolio structure as to a qualitative and quantitative direction.

The Risk Management Principle "Risk and Income" means that the Bank should not risk for a higher profit and a large portion of the credit resources should not be transferred to a large number of creditors. This can be achieved by the banks of the countries that work in the developed financial markets. As for developing countries where the financial market is not represented by all kinds of financial institutions, and the financial resources of production depend only on the banking sector, on the one hand, it increases the number of borrowers and on the other the risk of non-payment credit. For the construction of a credit risk assessment regression model, those factors should be allocated which are responsible for the credit and are affecting the financial and non-financial risk. However, it should be noted that none of the risks is classical and it is the result of a previously generated risk generation.

The internal factors affecting financial risks include Improper study of the borrower; Operating control hardness; Low-quality guarantee object; Bank's credit potential; Stability of deposits; Volume of reserves; Structure of the bank's commitment; Credit portfolio quality; Risk Management Level.

External factors: bankruptcy of the borrower; Unemployment; State of economics; Inflation rate; GDP growth rate; Change of the refinancing rate by the National Bank; Banking competition;

One of the challenging issues in credit risk assessment and management procedures is the determination of the probability of the default of the borrower in bankruptcy of the credit portfolio.

Depending on the global nature of banking risk management, there are a lot of methods and models of management, but according to the country's economic development, risk culture, the level of banking education, the legal regulatory - generator factors are different and accordingly the methods of minimizing it should vary from the methods applied. The growth of the globalization of financial institutions in the agenda put the necessity of gradually reaching the requirements of the European banking system. This process is complicated for countries that have been able to formulate an independent banking system and meet the demands of globalization simultaneously. The banking system of Georgia also develops under such difficult conditions. Risk management models have been created and evolved since the 70 s of the 20 th century.

The first model, the borrower's solvency is assessed, was evaluated by the American financier E. Altman, in 1968. according to which the borrower's solvency is determined by the financial coefficients. The models created after Altman it has become possible to predict the forecast of the probability of fulfilment of the obligation taken by the counterparty. These models were based on financial statements Data. That's right here, It is highly probable to get a large error in the results of models, for several reasons: 1. Quality of the protection of the principle of uncertainty in the balance reports by the company counterparts.

2. Changes in the after the condition of the assessment in the direction of deterioration. 
3. The worsening of the condition of the counterparty companies of the borrowers' company.

The use of these models in Georgian companies will increase credit risk quality, depending on the simple reality that financial statements still perform a certain dose of "make it beautiful" functioning of the financial position of the company, at the same time it is important to use sectoral ratings to ensure the correctness of the results obtained using the models, which has not yet been developed in Georgia. The creditworthiness of the borrower is a major measure of credit risk prevention, but the focus only on the solvency characteristics will provoke the ignoring of the other factors that also can cause credit risk.

\section{Methodology}

The main part of the study is the selection of regressive equations of credit and operational risk and conducting empirical analysis. When building the risk models, the Group of Internal Factors were taken into account, whose impact is high on the financial results of commercial banks.

For the credit risk measurement it was taken The ratio of total liabilities with total assets (dependent $\mathrm{Y}$ variable);

Independent variables:

1. Total liability / own capital - X1; 2. X2-ROE; 3. X3-ROA.

The regressive model was built as follows:

$\mathrm{Y}=\beta \_(0)+\beta \_1 \times \mathrm{X} 1+[\beta] \_2 \times \mathrm{X} 2+\beta \_(3) \times \mathrm{X} 3$

The study analyzes the credit risk based on the 11 years data of the Bank of Georgia (data from the audit accounts of the commercial bank). Dependence on credit risk factors is linear. Independent variables are calculated for each year according to 2007-2017 data. The purpose of the analysis is to determine the impact of the variability of economic indicators on credit risk annually

Table No1: The financial data of the bank XXX

\begin{tabular}{|c|c|c|c|c|c|}
\hline Years & liability & Own capital & Net profit & Capital & Assets \\
\hline 2007 & 2395620 & 557991 & 75642 & 557991 & 2953611 \\
\hline 2008 & 2540058 & 718849 & 174000 & 718849 & 3258907 \\
\hline 2009 & 2315012 & 598417 & -98908 & 598417 & 2913429 \\
\hline 2010 & 3311581 & 693341 & 82667 & 693341 & 4004922 \\
\hline 2011 & 3852658 & 812603 & 135710 & 812603 & 4665261 \\
\hline 2012 & 4594096 & 1061184 & 182745 & 1129786 & 5727018 \\
\hline 2013 & 5279919 & 1244315 & 213800 & 1244315 & 6524234 \\
\hline 2014 & 6076214 & 1461087 & 245984 & 1461087 & 7537301 \\
\hline 2015 & 7778938 & 1224607 & 260722 & 1224607 & 9003545 \\
\hline 2016 & 9499861 & 1265946 & 289094 & 1233144 & 10732932 \\
\hline 2017 & 11138797 & 1481919 & 338907 & 1481919 & 12620716 \\
\hline
\end{tabular}

Source: The National Bank of Georgia 
Table № 2: The economic indicators

\begin{tabular}{|l|c|c|c|c|c|c|c|c|c|c|c|}
\hline $\begin{array}{l}\text { Credit } \\
\text { Risk }\end{array}$ & 0.811082 & 0.77942 & 0.7946 & 0.826878 & 0.825818 & 0.802179 & 0.809278 & 0.806152 & 0.863986 & 0.885113 & 0.88258 \\
\hline $\begin{array}{l}\text { liability/ } \\
\text { Own capital }\end{array}$ & 4.293295 & 3.533507 & 3.86856 & 4.776266 & 4.741132 & 4.329217 & 4.243233 & 4.158694 & 6.352191 & 7.50416 & 7.516468 \\
\hline ROE & 0.135561 & 0.242054 & -0.16528 & 0.11923 & 0.167007 & 0.161752 & 0.171821 & 0.168357 & 0.212903 & 0.234437 & 0.228695 \\
\hline ROA & 0.02561 & 0.053392 & -0.03395 & 0.020641 & 0.029089 & 0.031909 & 0.03277 & 0.032636 & 0.028958 & 0.026935 & 0.026853 \\
\hline
\end{tabular}

Source: The financial reporting of the commercial bank

Table No3: The correlation matrix of the data of the economic indicators has the look

\begin{tabular}{|c|c|c|c|c|}
\hline & Row 1 & Row 2 & Row 3 & Row 4 \\
\hline Row 1 & 1 & & & \\
\hline Row 2 & $\mathbf{0 . 9 8 7 4 6 6}$ & 1 & & \\
\hline Row 3 & 0.412063 & 0.428932 & 1 & \\
\hline Row 4 & 0.05781 & 0.074484 & $\mathbf{0 . 9 3 2 1 8 1}$ & 1 \\
\hline
\end{tabular}

Source: Regression analysis, Authors' calculations

From the matrix it is seen that between the credit risk and the "liability/own capital" index is a strong linear connection, there is also a strong linear connection between $\mathrm{ROE}$ and ROA, which is not surprising, as both rankings depends on the size of the profit. Based on the selected multiple regression model, the $\beta$-coefficients are calculated.

$$
\text { Credit risk }=\beta_{0}+\beta_{1} \times \frac{\text { liabilities }}{\text { own capital }} .+\beta_{2} \times R O E+\beta_{3} \times R O A
$$

\begin{tabular}{|l|l|}
\hline & Coefficients \\
\hline B0 & 0.789332654 \\
\hline B1 & 0.002386698 \\
\hline B2 & 0.785352462 \\
\hline B3 & -3.808866234 \\
\hline
\end{tabular}

Credit risk $=0.789332654+0.002386698 \frac{\text { liabilities }}{\text { own capital }}+0.785352462 \mathrm{ROE}+-3.808866234 \mathrm{ROA}(3)$

The selected model evaluation using the $\mathrm{F}$ - test according to all the factors determining credit risk shows, that the model is selected correctly and the results received can predict the impact of the change of factors in future periods:

Table №4: the results of the regressive model and F-Test (2007-2017 Years)

\begin{tabular}{|c|c|c|c|c|c|c|c|}
\hline Assists & $d f$ & $S S$ & $M S$ & $F$ & Significance F & Multiple R & R Square \\
\hline Regression & 1 & \begin{tabular}{|c|}
$9,1113 E+13$ \\
\end{tabular} & $9,1113 \mathrm{E}+13$ & 152,6756573 & $1,71497 \mathrm{E}-06$ & \multirow{3}{*}{0,974787287} & \multirow{3}{*}{0,950210255} \\
\hline Residual & 8 & $4,7742 \mathrm{E}+12$ & $5,96775 \mathrm{E}+11$ & & & & \\
\hline Total & 9 & $9,58872 \mathrm{E}+13$ & & & & & \\
\hline Liabilities & $d f$ & SS & $M S$ & $F$ & & & \\
\hline Regression & 1 & $7,5052 \mathrm{E}+13$ & $7,5052 \mathrm{E}+13$ & 112,154162 & 5,52293E-06 & \multirow{3}{*}{0,966136051} & \multirow{3}{*}{0,933418869} \\
\hline Residual & 8 & $5,35349 \mathrm{E}+12$ & $6,69186 \mathrm{E}+11$ & & & & \\
\hline Total & 9 & $8,04055 \mathrm{E}+13$ & & & & & \\
\hline Own Capital & $d f$ & $S S$ & $M S$ & $F$ & & & \\
\hline Regression & 1 & $8,07617 \mathrm{E}+11$ & $8,07617 \mathrm{E}+11$ & 40,45759494 & 0,000218113 & \multirow[t]{3}{*}{0,913732565} & \multirow[t]{3}{*}{0,834907201} \\
\hline Residual & 8 & $1,59697 \mathrm{E}+11$ & 19962065059 & & & & \\
\hline Total & 9 & $9,67314 \mathrm{E}+11$ & & & & & \\
\hline Net Profit & $d f$ & $S S$ & $M S$ & $F$ & & & \\
\hline Regression & 1 & 90084519770 & 90084519770 & 14,92447852 & 0,004787042 & \multirow{3}{*}{0,806863092} & \multirow{3}{*}{0,651028049} \\
\hline Residual & 8 & 48288196948 & 6036024619 & & 1,71497E-06 & & \\
\hline Total & 9 & $1,38373 \mathrm{E}+11$ & & & & & \\
\hline
\end{tabular}


The results of regressive analysis show that the determinant coefficient besides, the net profit ratio is placed at 0,914-0,975 interval, there is also high the corrected determination coefficient $0,835-0,950$. This data gives us a reason to assume that the model explains the $95 \%$ of the data. Analyzing the financial reporting in the time gives the opportunity to review the relevant timelines. According to the table:

Table No.5: Change of Financial reporting Indexes in Time

\begin{tabular}{|l|c|c|c|c|c|}
\hline & Year & liabilities & Own capital & Net profit & Assets \\
\hline Year & 1 & & & & \\
\hline Liabilities & 0.95399 & 1 & & & \\
\hline Own capital & 0.930017 & 0.862117 & 1 & & \\
\hline Net profit & 0.806005 & 0.833208 & 0.857944 & 1 & \\
\hline Assets & 0.964401 & 0.998433 & 0.888912 & 0.847365 & 1 \\
\hline
\end{tabular}

Source: Regressive analysis, Authors' calculations

The matrix of correlation coefficients shows that the correlation coefficient of all values is greater than 0,83 . Analyzing the financial reporting in the time gives the opportunity to review the relevant timelines.

Table №6: forecasting data of financial reporting indicators

\begin{tabular}{|l|c|c|}
\hline \multirow{2}{*}{ The equation of time regression line of the time dependence } & \multicolumn{2}{|c|}{ prognosis } \\
\cline { 2 - 3 } & The 2018 year & The 2019 year \\
\hline liabilities $=-560942.0848+953793.1515 * \mathrm{i}$ & 10884575.73 & 11838368.88 \\
\hline Own capital $=413111.0485+98940.88485 *_{\mathrm{i}}$ & 1600401.667 & 1699342.552 \\
\hline Net profit $=-32316.61818+33044.41818 *_{\mathrm{i}}$ & 364216.4 & 397260.8182 \\
\hline Assets $=-132053.1636+1050904.564 *_{\mathrm{i}}$ & 1594041.133 & 1691174.648 \\
\hline
\end{tabular}

Source: Regressive analysis, Authors' calculations

Table No7: Comparison of forecast indicators (2017-2018-2019 years)

\begin{tabular}{|l|c|c|c|c|c|}
\hline Financial data & $\mathbf{2 0 1 7}$ & $\mathbf{2 0 1 8}$ & $\mathbf{\%}$ & $\mathbf{2 0 1 9}$ & $\mathbf{\%}$ \\
\hline liabilities & 11138797 & $10884575.73(-)$ & 2,3 & $11838368.88(+)$ & 8,7 \\
\hline Own capital & 1481919 & $1600401.667(+)$ & 7,9 & $1699342.552(+)$ & 6,2 \\
\hline Net profit & 228907 & $364216.4(+)$ & 59,1 & $397260.8182(+)$ & 9,1 \\
\hline Assets & 12071662 & $12478801.6(+)$ & 3,4 & $13529706.16(+)$ & 8,4 \\
\hline & & & & & \\
\hline liabilities/own capital & 7,5165 & $6.801152(-)$ & 9,5 & $6.966441(-)$ & 2,4 \\
\hline ROE & 0,2287 & $0.228486(-)$ & 0,09 & $0.234902(+)$ & 2,8 \\
\hline ROA & 0,0269 & $0.029187(+)$ & 7,4 & $0.029362(+)$ & 0,7 \\
\hline Credit risk & 0,8826 & $0.873838(-)$ & 0,99 & $0.878604(+)$ & 0,01 \\
\hline
\end{tabular}

Source: Authors' calculations

The accuracy of the selection of the regression model is well illustrated in the prediction data. Compared to 2017, the liabilities decrease in 2018 and thus the volume of assets increases, so credit risk slightly reduces. The commercial bank must expect a steady increase in 2019, as both the credit risk determiners are increasing and at least the thousandths change of credit risk will not become a subject of discussion.

The changes shown in percentages do not accurately show evidence obtained by correlation, But in our work, we noted that correlation of credit risk and its factors can 
be considered a linear if the dependency schedule includes linear areas. Depending on the credit risk and the financial indicators, there is no accurate reflection of the direction of correlation in our view, ignoring the influence of these indicators. The value of the correlation coefficient and the set of sample parameters of the regression model assures us that the forecast parameters correspond to high probability events.

\section{Operation risk $=\beta_{0}+\beta_{1} \times \frac{\text { total liabilities }}{\text { own capital }} .+\beta_{2} \times \frac{\text { overdue credit }}{\text { total credit }}+\beta_{3} \times$ $\frac{\text { total operational expenses }}{\text { total capital }}+\beta_{4} \times \frac{\text { credit liquidity }}{\text { total depossits }}$

Let's review changes the financial reporting liabilities in time, ie The time series of these time rows.

Table №8: The Correlation coefficient

\begin{tabular}{|l|c|c|c|c|c|c|c|c|c|}
\hline & Time & Liabilities & $\begin{array}{c}\text { Own } \\
\text { capital }\end{array}$ & $\begin{array}{c}\text { Overdue } \\
\text { credit }\end{array}$ & $\begin{array}{c}\text { Total } \\
\text { credit }\end{array}$ & $\begin{array}{c}\text { Operating } \\
\text { expenses }\end{array}$ & Assets & $\begin{array}{c}\text { Net } \\
\text { profit }\end{array}$ & $\begin{array}{c}\text { Equity } \\
\text { capital }\end{array}$ \\
\hline Time & 1 & & & & & & & & \\
Liabilities & $\mathbf{0 . 9 5 3 9 9}$ & 1 & & & & & & \\
Own capital & 0.930017 & 0.862117 & 1 & & & & & \\
Overdue credit & 0.667158 & 0.709929 & 0.460035 & 1 & & & & \\
Total credit & 0.738687 & 0.859959 & 0.593814 & 0.841582 & 1 & & & \\
Oper.expenses & $\mathbf{0 . 8 0 7 5 6 1}$ & 0.752576 & 0.678264 & 0.794675 & 0.716621 & 1 & & & \\
Assets & 0.963907 & 0.998593 & 0.887773 & 0.693019 & 0.843323 & 0.75461 & 1 & & \\
Net profit & 0.806005 & 0.833208 & 0.857944 & 0.41728 & 0.659897 & 0.550706 & 0.84665 & 1 \\
Equity capital & 0.939482 & 0.877761 & 0.997403 & 0.472294 & 0.624482 & 0.68897 & 0.901717 & 0.856887 & 1 \\
\hline
\end{tabular}

Source: Regression analysis

The matrix of correlation coefficients shows that liabilities, own capital, assets and equity increases with the increase of time, as the corresponding correlation coefficients are the values close to 1 . Also, using a linear regression model, we can review the operating expenses and net profit time lines, besides we can compare the periods of credits and overdue credits to a relatively weak lineup, as their correlation coefficients are close to 0,7 .

Table№ 9: Forecasting data of financial reporting indicators

\begin{tabular}{|l|c|c|}
\hline \multirow{2}{*}{ The equation of time regression line of the time dependence } & \multicolumn{2}{|c|}{ Prognosis } \\
\cline { 2 - 3 } & The 2018 year & The 2019 year \\
\hline liabilities $=-560942.0848+953793.1515 *_{\mathrm{i}}$ & 10884575.73 & 11838368.88 \\
\hline Own capital $=413111.0485+98940.88485 \mathrm{i}$ & 1600401.667 & 1699342.552 \\
\hline Net profit $=-32316.61818+33044.41818 *_{\mathrm{i}}$ & 364216.4 & 397260.8182 \\
\hline Assets $=-147691.6424+1052727.976 *_{\mathrm{i}}$ & 12485044.07 & 13537772.04 \\
\hline Equity capital $=369260.7576+101789.5758 *_{\mathrm{i}}$ & 1590735.667 & 1692525.242 \\
\hline Overdue credit $231359.303+26372.8303 *_{\mathrm{i}}$ & 547833.2667 & 574206.097 \\
\hline Total credit $=7535.818182+12668.58182 *_{\mathrm{i}}$ & 103098.4 & 110634.2182 \\
\hline Operating expenses $=418040.9152+42506.55152 * 1$ & 928119.5 & 970626.1 \\
\hline
\end{tabular}

Source: The results of the regressive analysis

Due to the weak correlation of overdue loans, total credits and operating expenses, connections using this model are explained as overdue loan $-54 \%$; Total credit score $-73 \%$; Operating expenses $-78 \%$. The weak link does not necessarily mean excluding these factors from operating risk assessment, but when risk management is to 
rank factors it should be taken into consideration that the indicators which are explained with low percentage using this model are intended to enhance their attention in the expert evaluation process.

Table №10: Results of Regression Model and F-Test (2007-2017) - Operational Risk

\begin{tabular}{|c|c|c|c|c|c|c|}
\hline Regression Analysis & Operation risk & & & & & \\
\hline \multicolumn{7}{|l|}{ Regression Statistics } \\
\hline Multiple R & 0.999426805 & & & & & \\
\hline R Square & 0.998853939 & & & & & \\
\hline Adjusted R Square & 0.99793709 & & & & & \\
\hline Standard Error & 0.01435078 & & & & & \\
\hline Observations & 10 & & & & & \\
\hline \multicolumn{7}{|l|}{\begin{tabular}{|l|} 
ANOVA \\
\end{tabular}} \\
\hline & $d f$ & $S S$ & $M S$ & $F$ & Significance $F$ & \\
\hline Regression & 4 & 0.897460275 & 0.224365069 & 1089.442217 & $1.55501 \mathrm{E}-07$ & \\
\hline Residual & 5 & 0.001029725 & 0.000205945 & & & \\
\hline \multirow[t]{2}{*}{ Total } & 9 & 0.89849 & & & & \\
\hline & Coefficients & Standard Error & tStat & P-value & Lower 95\% & Upper 95\% \\
\hline Free member & -0.129747421 & \begin{tabular}{|l|}
0.042727278 \\
\end{tabular} & -3.036641381 & 0.028861353 & -0.239581386 & -0.019913456 \\
\hline Liability/Equity capital & -0.000660436 & 0.004576719 & -0.144303413 & 0.890896921 & -0.012425266 & 0.011104394 \\
\hline Overdue credits /Total credits & -0.000897984 & 0.002754255 & -0.326035321 & 0.757601131 & -0.007978022 & 0.006182053 \\
\hline Operating expenses/Assets & 0.423208923 & 0.2016852 & 2.098363795 & \begin{tabular}{|l|}
0.08993981 \\
\end{tabular} & -0.09523939 & 0.941657236 \\
\hline Liquid assets /Deposits & 0.319935385 & 0.008125503 & 39.37422715 & $1.99181 \mathrm{E}-07$ & 0.299048116 & 0.340822654 \\
\hline
\end{tabular}

Source: Regression analysis

As the chart shows the determination coefficient, as well as the corrected determination coefficient, is 0.99 , which gives us the basis to estimate that $99 \%$ of the data are explained by the model and the model is correctly selected.

Regressive model depending on the factors of operational is the following:

Operating Risk $=-0.129747421-0.000660436 \times$ liability $/$ Equity capital $0.000897984 \times$ Overdue credits/Total credits $+0.423208923 \times$ Operation expenses /Assets $+0.319935385 \times$ liquid assets/ deposits. (5)

Table No11: Comparison of forecast indicators (2017-2018-2019) - Operational risk

\begin{tabular}{|l|c|c|c|c|c|}
\hline Financial data & $\mathbf{2 0 1 7}$ & $\mathbf{2 0 1 8}$ & $\mathbf{0}$ & $\mathbf{2 0 1 9}$ & $\mathbf{\%}$ \\
\hline Liabilities & 11138797 & $10884575.73(-)$ & 2,3 & $11838368.88(+)$ & 8,7 \\
\hline Own capital & 1481919 & $1600401.667(+)$ & 7,9 & $1699342.552(+)$ & 6,2 \\
\hline Overdue credits & 551380 & $547833.3(-)$ & 0,7 & $574206.1(+)$ & 4,8 \\
\hline Operating expenses & 1028342 & $928119.5(-)$ & 9,7 & $970626.1(+)$ & 4,5 \\
\hline Equity capital & 1481919 & $1590736(+)$ & 7,3 & $1692525(+)$ & 6,3 \\
\hline Net profit & 228907 & $364216.4(+)$ & 59,1 & $397260.8182(+)$ & 9,1 \\
\hline Assets & 12071662 & $12478801.6(+)$ & 3,4 & $13529706.16(+)$ & 8,4 \\
\hline Total credit score & 171106 & $103098.4(-)$ & 39,7 & $110634.2182(+)$ & 7,3 \\
\hline & & & & & \\
\hline Liabilities /own capital & 7,52 & $6.842479(-)$ & 9,0 & $6.994501(+)$ & 2,4 \\
\hline Overdue credits/Total credits & 3,22 & $5.313693(+)$ & 0,09 & $5.190131(-)$ & 2,8 \\
\hline Operating expenses/Assets & 0,08 & $0.074339(-)$ & 7,4 & $0.071698(-)$ & 0,7 \\
\hline Liquid assets/Deposits & 0,40 & 0.4 & 0 & 0.4 & 0 \\
\hline Operation Risk & 0,03 & $\mathbf{0 . 0 2 0 3 9 7 ~ ( - )}$ & 0,99 & $\mathbf{0 . 0 1 9 2 9}(-)$ & 0,01 \\
\hline
\end{tabular}

Source: Authors' calculations 


\section{Results}

The correlation of risk factor of "Overdue Loan / Equity Capital" to the operation risk is negative, and accordingly, the increase in one is causing the reduction of the other. This regularity is fulfilled with regard to the 2019 forecast parameter. The negative correction has also been fixed with "overdue credit/jumper credit", and the normality of 2018 is to be fulfilled.

\section{Discussion}

As regressive analysis has been revealed that some percentage of the explanation given by this model is low (overdue credits; Total Credit and Operational expense). It is interesting what their influence on Operational Risk is: According to the values listed in the table there should be a correct regressive link between the listed indicators and the operational risks by 2018 and by 2019 still there is a disorder. However, the reasoning has been based on forecasting indicators and it is expected to change the coefficients calculated by other (external) factors.

\section{Conclusion}

Thus, the regressive analysis carried out by the country's system bank confirms that banking risks (credit and operational) are factors correlated with these risks. An analysis of the financial data, risk factors brought in the audit report of the commercial banks of the banking system of Georgia, expert assessments, research scholarship approach to risk management models was founded as a basis for compiling the regressive equations. High coefficient of the regression model determination confirmed the accuracy of the chosen model. The small inconsistencies between the size of the risk and current factors according to the correlation coefficient are conditioned by the intense interaction of activating other risks in the banking sector short intervals of time. The research revealed the factors that effectively affect financial and non-financial risks.

The overdue loan, despite the $54 \%$ recurrence in the model, shows that its impact on the operational risk is statistically significant, which has been confirmed in the forecasting indicators. Net Profit/Total assets which are directly Definitive Indicators of the operational risk are positively correlated with operational risk, but unequal growth of constituent components has reduced operational risk. We are justified to evaluate credit and operational risks with economic indicators.

We believe that the conclusion made with this method will give risk management to the right direction for the development of risk reduction measures because risk management is part of financial management, these economic indicators will be controlled by financial management, and risk management is likely to give more time to detect and manage other risks.

In addition to the operational risk assessment with the regressive model, The risk management of the Bank should take into consideration the possibility of influence on the operating risk to the Bank's reputation, Human capital development, the 
company's intangible assets, which is a precondition for increasing customer base and successful performance of the Bank.

\section{References}

Aver Boštjan, "An Empirical Analysis of Credit Risk Factors of the Slovenian Banking System”, Managing Global Transitions, 2008, vol. 6, issue 3,

Beverly Hirtle J., "What Market Risk Capital Reporting Tells Us about Bank Risk" 2003, https://www.newyorkfed.org/research/epr/03v09n3/0309hirt/0309hirt.html

Gustafsson Martin and Morck Erik, "Black-Scholes Option Pricing Formula-An Empirical Study", School of Business, Economics and Law, Goteborg University, 2008

Hanley M. "Integrated Risk Management", London, LLP, 2000

Harper David, "Understanding Liquidity Risk", 2017

Jakubik Petr, „Macroeconomic Credit Risk Model,“ ResearchGate“,2006

Musau Salome, Muathe Stephen and Mwangi Lucy, "Financial Inclusion, GDP and Credit Risk of Commercial Banks in Kenya", "International Journal of Economics and Finance" Vol. 10, No. 3; Published by Canadian Center of Science and Education, 2018

Papadopoulos George, Papadopoulos Savac and Sager Thomas "credit risk stress testing for EU 15 banks: a model combination approach", "Bank of Greece, Economic Analysis and Research Department" - Special Studies Division21, January 2016

Perold Andre F., "The Capital Asset Pricing Model", Journal of Economic Perspectives, Volume 18, Number 3, 2004

Zhu Wenzhong and Rui Shen, "The Historical Dimension of the US Dodd-Frank Bill and its Implications to the Financial Governance Reform in Emerging Markets", Published Scientific Research, 2013 